\title{
Pendidikan Islam dan Pengembangan Kesadaran Lingkungan
}

\author{
Endang Syarif Nurulloh \\ Institut Agama Islam Latifah Mubarokiah (IALM) Tasikmalaya, Jawa Barat \\ Email: endangsyarifnurulloh@gmail.com
}

Received: February 2, 2019 | Accepted: May 14, 2019

\begin{abstract}
Development of awareness of the importance of the environment is a journey that must be pioneered for the sake of the survival of the next generation so that it is not threatened due to irresponsible human behavior today. Environmental education aims at introducing various values and explaining concepts to develop the ability of attitudes and skills needed to understand and appreciate the mutual relations between humans, culture, and the biophysical environment. This study aims to dig deeper about the development of environmental awareness in Islamic education. This study uses the literature study method by making a number of the results of the studies of previous researchers as the main data source. The results showed that the development of environmental awareness can be implemented through religious values with an environmental perspective in Islamic educational institutions. The religious climate in the environment in Islamic educational institutions can be realized through approaches: the creation of a religious education environment; the realization of worship facilities; the realization of the learning method by using the approach of religious values in every learning, especially religious values with an environmental perspective; dan the realization of the example of educators who have noble morals in particular having a concern for the environment.
\end{abstract}

\begin{abstract}
Abstrak
Pengembangan kesadaran pentingnya lingkungan hidup merupakan sebuah proses perjalanan yang harus dirintis demi keberlangsungan hidup pada generasi berikutnya agar tidak terancam akibat perilaku manusia yang tidak bertanggungjawab dewasa ini. Pendidikan lingkungan bertujuan mengenalkan berbagai nilai dan menjelaskan konsep untuk mengembangkan kemampuan sikap dan keterampilan yang dibutuhkan dalam memahami dan menghargai hubungan timbal balik antara manusia, budaya, dan lingkungaan biofisika. Kajian ini bertujuan untuk menggali lebih mendalam tentang pengembangan kesadaran lingkungan dalam pendidikan Islam. Kajian ini menggunakan metode kajian pustaka dengan menjadikan sejumlah hasil kajian para peneliti terdahulu sebagai sumber data utamanya. Hasil penelitian menunjukkan bahwa pengembangan kesadaran lingkungan dapat diimplementasikan melalui nilai-nilai keagamaan berbasis lingkungan di lembaga pendidikan Islam. Iklim keagamaan di
\end{abstract}


lingkungan dalam lembaga pendidikan Islam dapat diwujudkan melalui pendekatan: terciptanya lingkungan pendidikan agamis; terealisasinya sarana peribadahan; terwujudnya metode pembelajaran dengan menggunakan pendekatan nilai-nilai agamis dalam setiap pembelajaran khususnya nilai-nilai agama yang beberbasis lingkungan; dan terwujudnya teladan dari pendidik yang memiliki akhlak mulia khususnya memiliki kepedulian terhadap lingkungan.

\section{Keywords}

Islamic education, environmental awareness, environmental care.

\section{Pendahuluan}

Merintis dan mengembangkan program kesadaran lingkungan dalam dunia pendidikan merupakan pekerjaan yang tidak mudah. Tantangan terberat yang harus dihadapi adalah kebiasaan membuang sampah sembarangan, pola hidup kurang bersih, dan perilaku hidup boros (Herdiansyah, 2018). Hal tersebut bisa terlihat dari keberadaan sampah yang berserakan di halaman sekolah, debu yang menempel pada kaca dan meja kelas, juga penggunaan air dan kertas yang berlebihan. Jika hal itu tidak diubah sejak dini, maka perilaku hidup tidak ramah lingkungan tersebut akan membudidaya hingga kehidupan berikutnya. Menanggulangi permasalahan lingkungan harus dimulai dari proses menanggulangi perilaku manusia, karena manusia merupakan penyebab terjadinya berbagai permasalahan lingkungan (Fua, 2013). Pengembangan kesadaran akan pentingnya lingkungan hidup merupakan sebuah proses perjalanan yang harus dirintis demi keberlangsungan hidup pada generasi berikutnya agar tidak terancam akibat perilaku manusia yang tidak bertanggungjawab dewasa ini. Kesadaran lingkungan akan tercapai jika pembentukanya diupayakan sejak dini secara terus-menerus melalui sebuah pembiasaan. Langkah strategis dalam penanaman kesadaran lingkungan dilakukan melalui pendidikan lingkungan (Jufri, 2018, p. 166).

UNESCO tahun 1970 menerangkan bahwa pendidikan lingkungan merupakan sebuah proses dalam rangka mengenalkan berbagai nilai dan menjelaskan konsep untuk mengembangkan kemampuan sikap dan keterampilan yang dibutuhkan dalam memahami dan menghargai hubungan timbal balik antara manusia, budaya, dan lingkungan biofisika (Herdiansyah, 2018, p. 51).

Seluruh lembaga pendidikan seharusnya memiliki tanggung jawab untuk mewujudkan kesadaran lingkungan terhadap peserta didik. Oleh karena itu diperlukan sebuah upaya melalui program terencana yang mampu 
mengimplementasikan perwujudannya di setiap institusi sekolah. Pendidikan sudah seharusnya dimanfaatkan sebagai sarana untuk pembentukan sikap yang memiliki kepedulian terhadap lingkungan secara efektif. Pendidikan yang kurang memberikan informasi masalah lingkungan akan memberikan dampak terhadap kurangnya pengetahuan peserta didik yang dapat berakibat lahirnya sikap kurang peduli terhadap lingkungan. Melalui proses pendidikan lingkungan yang intensif akan meningkatkan kualitas perilaku yang positif terhadap lingkungannya, hal ini dikarenakan pendidikan mampu mewujudkan kesiapan mental peserta didik dan memiliki keinginan untuk melakukan hal yang bersifat positif terhadap objek tertentu, objek tertentu di sini adalah sikap dan atau perilaku yang positif terhadap lingkungan (Hasnidar, 2019, p. 101).

Pada dasarnya "pendidikan" tidak bisa Terpisahkan dari lingkungan, karena sejak manusia dilahirkan dengan serta merta berinteraksi dan butuh lingkungan untuk tumbuh dan berkembang menjadi manusia dewasa. Sehingga pola pikir manusia telah dikonstruk oleh segala sesuatu yang terjadi di sekitar lingkunganya. Dengan demikian, keberadaan lingkungan menjadi kewajiban setiap manusia untuk tetap mempertahankan segala potensi yang dimiliki oleh lingkungan itu sendiri. Akan tetapi, kenyataannya telah terjadi pemisahan antara dunia pendidikan dengan lingkungannya, bahkan telah tercerabut secara paksa dari kehidupan lingkungannya. Berdasarkan realita tersebut, maka sudah seharusnya lembaga pendidikan Islam menerapkan pendidikan dengan berbasis lingkungan sehingga setiap langkah dunia pendidikan Islam merupakan wujud dari penyerapan dunia lingkungan yang ditempatinya dan setiap yang terjadi di lingkungannya merupakan perwujudan dari segala hal yang telah dipelajari di dunia pendidikannya (Obaid, 2013, p. 141).

Pendidikan Islam harus menjadi pelopor dalam pengembangan kesadaran lingkungan, karena konsep pendidikan lingkungan telah lahir sejak Islam dibawa oleh Nabi Muhammad Saw. dan Alquran mengajarkan bagaimana seharusnya umat Islam memperlakukan lingkungan alam. Di dalam Al Qur'an surat Al-A'raf ayat 56 Allah menjelaskan:

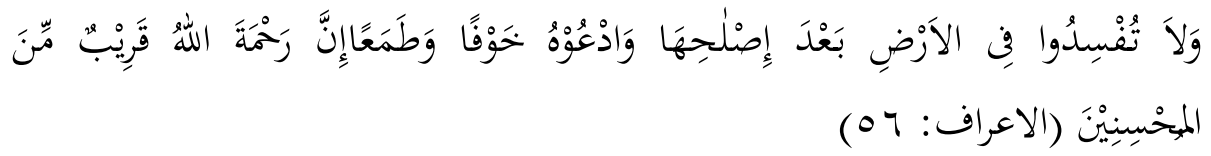

Janganlah kamu berbuat kerusakan di bumi, setelah (Allah) memperbaikinya, dan Berdoalah kepada Allah dengan penuh rasa takut (tidak akan diterima) dan berharap (akan dikabulkan). Sesungguhnya rahmat Allah Swt. begitu dekat bagi orang-orang yang berbuat baik.

Pendidikan Islam merupakan serangkaian proses dalam pembentukan manusia menuju kedewasaan, baik intelektual, spiritual, maupun emosional 
agar mampu menjalankan fungsi kemanusiaannya sebagai hamba Allah Swt. dan sebagai pemelihara alam semesta. Hal tersebut menunjukkan fungsi pendidikan Islam sebagai media untuk mempersiapkan peserta didik terjun di tengah-tengah masyarakat (Haryanti, 2017, p. 1).

Oleh karena itu, pendidikan Islam sudah seharusnya beriringan dan bersinergi dengan pendidikan lingkungan melalui kegiatan praktik lingkungan secara langsung berdasarkan ajaran ekologi agama Islam. Menurut para ahli dan aktivitas lingkungan, Pandangan tersebut saat ini dinyatakan sebagai wujud dari penggalian sistem nilai baru yang harus disesuaikan dengan kehidupan manusia yang serba modern, tanpa disertai niat untuk menolak berbagai tuntunan ajaran yang menjadi penghubung antara Islam dan ekologi. Pandangan tersebut didukung oleh mayoritas ajaran agama yang telah memberikan kontribusi terhadap intervensi pendidikan sebagai salah satu faktor penting dalam menumbuhkembangkan kesadaran manusia akan keberadaan lingkungannya dan memberikan dampak positif berupa aksi dalam menyikapi berbagai problematika lingkungan (Asmanto, 2015, p. 336).

Harapan dari penerapan pendidikan berbasis lingkungan adalah adanya keterikatan antara moril peserta didik dengan berbagai materi pembelajaran di lembaga pendidikan, karena materi yang dipelajari oleh peserta didik merupakan bagian tak terpisahkan dari kehidupan sehari-hari.

\section{Metode}

Penelitian ini menggunakan jenis penelitian kualitatif non interaktif dengan menggunakan metode analisis konsep/isi (teks). Karena penelitian yang dilakukan adalah meneliti setiap teks/isi yang terdapat dalam beberapa jurnal yang berhubungan dengan pengembangan kesadaran lingkungan dalam pendidikan Islam. Jenis data dalam penelitian ini merupakan gambaran umum tentang bentuk pengembangan kesadaran lingkungan dalam pendidikan Islam. Sumber data dalam penulisan ini, menggunakan dua sumber yaitu data primer berupa beberapa jurnal yang berkaitan dengan pengembangan kesadaran lingkungan dalam pendidikan Islam, dan data sekunder berupa buku-buku tentang lingkungan dan pendidikan Islam yang ada kaitannya dengan pengembangan kesadaran lingkungan. Data yang telah dikumpulkan selanjutnya dianalisis dengan menggunakan metode analisis isi (Content Analysis. Analisis ini dikembangkan sebagai upaya penggalian lebih lanjut mengenai pengembangan kesadaran lingkungan dalam pendidikan Islam. 


\section{Hasil dan Pembahasan}

Islam adalah agama yang sangat memperhatikan lingkungan. Banyak sekali ayat-ayat Alquran dan as-Sunnah yang berisi pembahasan tentang lingkungan. Pesan-pesan yang disampaikan Alquran tentang lingkungan sangat jelas dan prospektif. Pesan-pesan tersebut berisi perintah untuk melakukan penjagaan dan pemeliharaan terhadap lingkungan yang harus dilakukan oleh manusia (Sutoyo, 2015, p. 59).

Dalam perspektif Islam, manusia diciptakan sebagai makhluk terbaik di antara ciptaan Allah Swt. (QS. 95:4; 17:70) dia diangkat sebagai khalifah (QS. 2:30) dan memiliki tanggung jawab untuk mengelola bumi serta memakmurkannya (QS. 33:72). Berdasarkan fungsinya sebagai khalifah, manusia diperintahkan untuk beribadah kepada Allah Swt. dan berbuat kebajikan serta dilarang berbuat kerusakan, (QS. 28:77), manusia dilarang berbuat kerusakan di bumi setelah diciptakan dengan baik (QS. 7:56), dan manusia dilarang menuruti perintah orang-orang yang berbuat kerusakan dan tidak melakukan perbaikan (QS. 26: 151-152). Islam merupakan rahmat bagi alam semesta. Karena kesempurnaan ajarannya akan menuntun manusia untuk menciptakan kehidupan yang serasi, adil, selaras, dan seimbang bagi seluruh manusia, alam, dan seluruh makhluk di muka bumi ini (Sutoyo, 2015, p. 58).

Sebagai agama yang rahmat li al-'alamîn, Islam telah mengatur adab terhadap lingkungan. Hal tersebut dapat ditemukan dalam prosesi pelaksanaan ibadah haji. Ketika jamaah haji mulai berniat melakukan ihram atau memasuki tanah Haram, maka para jamaah pun tidak diperkenankan untuk menumbangkan pepohonan, menyakiti binatang, bahkan rumput sekalipun dilarang untuk memetiknya. Konsep pelestarian lingkungan pun telah diimplementasikan oleh Nabi Muhammad melalui program kawasan lindung (bima), yaitu sebuah kawasan khusus yang dilindungi pemerintah dengan tujuan melestarikan kehidupan ekosistem di hutan. Nabi juga pernah membuat cagar alam di sekitar Madinah sebagai hima dengan tujuan untuk melindungi lembah, dan tumbuhan yang berada di dalamnya. Konsep ihya'ul mawât juga diperkenalkan dalam Islam, yaitu sebuah usaha dalam pengelolaan lahan yang masih belum bermanfaat menjadi berdaya guna bagi kebutuhan manusia. Selain tumbuhan, Nabi Muhammad Saw. pun sangat peduli terhadap kelestarian hewan, sebagaimana halnya diceritakan dalam sebuah hadis yang diriwayatkan oleh Abu Daud. Nabi Muhammad memperingatkan seorang sahabat pada saat perjalanan karena telah mengambil anak burung dari sarangny, sehingga sang induk burung mengikuti langkah ke mana pun rombongan berjalan. Melihat hal tersebut, Nabi Muhammad Saw. mengatakan "Siapakah yang telah menyusahkan induk burung ini dan mengambil anaknya, 
kembalikanlah anak-anak burung tersebut kepada induknya" (Fua, 2013, p. 117).

Berdasarkan keterangan tersebut, aturan-aturan dalam Islam dengan jelas menganjurkan manusia untuk menjaga dan memelihara kelestarian lingkungan. Maksud dari aturan tersebut adalah untuk mencegah terjadinya musibah yang diakibatkan dari perusakan lingkungan.

Dalam melakukan interaksi dan pengelolaan alam serta lingkungan, manusia diberikan tiga amanat oleh Allah Swt. Pertama, hubungan al-intifa', artinya manusia dipersilakan untuk mengambil manfaat dari alam dan memanfaatkannya kembali demi kemakmuran dan kemaslahatan. Kedua, hubungan al-i'tibar, artinya manusia diperintahkan untuk dapat mengambil pelajaran dari berbagai peristiwa alam. Ketiga, hubungan al-islah, artinya manusia diwajibkan untuk terus menjaga dan memelihara kelestarian lingkungan itu. Artinya, manusia yang hidup di tengah-tengah lingkungan semesta alam dengan segala kekuatan dan kekayaannya seharusnya mampu menempatkan diri hubungannya dengan mengambil manfaat, mengambil pelajaran dan melestarikan alam. Begitu banyak Alquran menunjukkan maksud ini. Contohnya, apa yang ada di sekitar manusia merupakan mata'an lakum wa li'an'amikum, "yang berarti suatu kenikmatan, kesenangan fasilitas bagimu" (Q.S. 79: 33 dan QS. 80: 32) (Obaid, 2013, p. 140).

Menurut Mahmudi asyari, pemeliharaan alam sama dengan penjagaan terhadap aspek yang terkait dengan al-usul al-khamsah di dalam materi usul alfiqh yakni hifz ad-din (pemeliharaan agama), hifz an-nafs (pemeliharan jiwa), hifz al-'aql (pemeliharaan akal), hifz al-mal (pemeliharaan harta), dan hifz al'ardl (pemeliharaan kehormatan). Dan jika perlu penambahan, maka hifz al-bi 'ah (pemeliharaan lingkungan) lebih tepat untuk ditambahkan, mengingat keberlangsungan kehidupan manusia tidak bisa lepas dari alam dan lingkungannya. Hal tersebut membuktikan bahwasanya ajaran Islam merupakan ajaran yang proporsional, meliputi berbagai aspek kehidupan dan disesuaikan dengan perkembangan zaman (Purwidianto, 2017, p. 227).

Dari uraian tersebut, perspektif lingkungan dalam Islam tidak hanya berada pada tataran normatif saja, tetapi telah dicontohkan dalam perjalanan risalah Nabi Muhammad Saw. oleh karena itu, sebagai umat Islam sudah seyogianya melakukan upaya untuk menumbuhkembangkan kesadaran lingkungan melalui pendidikan lingkungan khususnya pada umat Islam yang mampu memberikan hasil luar biasa dalam pencegahan perusakan lingkungan bahkan dalam perbaikan kerusakan yang telah terjadi. Kesadaran itu sendiri merupakan salah satu faktor yang mampu menentukan wujud perbuatan seseorang dan mendukung upaya pelestarian lingkungan. Kemauan bersikap dan kesediaan melestarikan lingkungan harus dipersiapkan sejak dini agar arus 
kesadaran seseorang dapat dikembangkan dengan baik. Menururt al-Ghazaly kesadaran adalah dimensi amal bathiniyah yang berpusat pada manajemen hati. Kesadaran merupakan gejala kejiwaan yang ditandai dengan tumbuhnya sebuah pengertian sebagai produk interelasi dari kemampuan internal manusia (Muslim, 2003, p. 46).

Berdasarkan hal tersebut kesadaran memiliki fungsi sebagai kontrol untuk diri sendiri dan lingkungan yang memberikan dampak terciptanya tujuan kelestarian lingkungan hidup. alasan tercapainya hal itu adalah: 1) pemahaman isi kandungan dari ayat-ayat Alquran merupakan respon dari masyarakat yang beragama dan dijadikan pedoman dasar dalam berperilaku sebagaimana halnya telah dicontohkan oleh Nabi Muhammad Saw. dan para sahabatnya; 2) praktek ajaran Islam yang turun temurun selanjutnya diikuti dengan baik dan benar. Iman yang yang terdiri dari unsur keyakinan dalam hati, dinyatakan dengan lisan, dan direalisasikan dalam perbuatan nyata. Atas dasar hal tersebut, pengalaman beragama mampu membentuk sebuah respon terhadap ajaran Islam dalam bentuk pikiran, perkataan dan perbuatan. Jika perbuatan tersebut dibiasakan dalam kehidupan sehari-hari, maka akan melahirkan sebuah pemahaman dan kesadaran yang akan terbentuk oleh lembaga pendidikan Islam dalam membentuk perilaku yang peduli terhadap lingkungan. Ajaran Islam tidak hanya terpokus pada pembentukan sikap humanis dengan sesama manusia akan tetapi mampu membentuk sikap humasis terhadap kehidupan sehingga lahirlah keseimbangan ekosistem dalam lingkungan (Karim, 2017, p. 323).

\section{Internalisasi Nilai-Nilai Keagamaan Berbasis Lingkungan}

Lingkungan terdiri dari material dan stimuli yang bersifat fisiologis, psikologis, dan sosio-kultural serta berada pada setiap individu baik di dalam maupun di luar individu itu sendiri. Lingkungan yang bersifat fisiologis adalah segala sesuatu yang meliputi kondisi dan material jasmaniah tubuh manusia, sedangkan lingkungan yang bersifat psikologis adalah segala sesuatu yang meliputi stimulus yang selalu diterima oleh setiap individu sejak dalam kandungan, kelahiran, hingga ajal tiba, sedangkan lingkungan yang bersifat sosio-kultural adalah segala sesuatu yang terdiri dari stimulasi dan interaksi serta kondisi eksternal individu yang berkaitan dengan perlakuan orang lain (Obaid, 2013, p. 144).

Agama adalah pondasi yang mampu memperkuat keyakinan dan memberikan arahan positif terhadap sikap dan perilaku masyarakat. Semakin tinggi keyakinan keberagamaan maka peluang mengembangkan kesadaran berperilaku baik semakin kuat. Agama telah menyuruh manusia untuk tidak melakukan perusakan terhadap lingkungan bahkan diperintahkan untuk 
menjaga kelestariannya untuk menghindari terjadinya bencana alam. Dengan demikian sikap menjaga kelestarian lingkungan merupakan sedekah yang sangat mahal untuk masa depan anak cucu secara kesinambungan. Oleh karena itu, hendaknya nilai-nilai agama berbasis lingkungan tersebut selalu ditanamkan kepada peserta didik dalam setiap pembelajaran agar tertanam di jiwa mereka dan mengakar dengan kuat (Karim, 2017, p. 322).

Kenyataan yang terjadi saat ini adalah Islam dipersempit hanya sebatas permasalahan hubungan dengan Allah Swt. (habl min Allah) dan hubungan dengan manusia ( habl min al nas). Ketika melakukan kesalahan hubungannya dengan perintah Allah Swt. (dalam hal ibadah) maka akan dianggap dosa. Demikian juga jika berbuat kesalahan terhadap manusia. Tetapi ketika melakukan kesalahan terhadap lingkungan hidup (alam), hal tersebut dianggap lumrah dan tidak pernah berpikir dengan masalah dosa. Padahal, jika dianalisis perbuatan kesalahan terhadap lingkungan hidup akan memberikan dampak yang lebih luas dan dirasakan oleh kehidupan generasi selanjutnya. Di sisi lain adanya kesenjangan dalam ajaran Islam antara teori dan praktik. Secara teori, Islam menjelaskan bahwa perusakan lingkungan termasuk pelanggaran atas perintah Allah swt. Namun kenyataannya, perusakan lingkungan terus menerus dilakukan. Hal tersebut terjadi ketika pengajaran agama dilakukan secara parsial dan tidak komprehensif sehingga pemahaman akan ajaran Islam hanya sepotong-sepotong, dan akhirnya pemeliharaan lingkungan hidup menjadi ajaran Islam yang terlupakan sehingga perlu waktu untuk menumbuhkan kembali kesadaran lingkungan dan harus dilakukan dengan segera melalui peranan lembaga pendidikan yang dirancang dengan iklim keagamaan (Purwidianto, 2017, p. 223).

Iklim keagamaan di lingkungan dalam lembaga pendidikan Islam dapat diwujudkan melalui pendekatan (1) terciptanya lingkungan pendidikan agamis, 2) terealisasinya sarana peribadahan, 3) terwujudnya metode pembelajaran dengan menggunakan pendekatan nilai-nilai agamis dalam setiap pembelajaran khususnya nilai-nilai agama yang berbasis lingkungan 4) terwujudnya teladan dari pendidik yang memiliki akhlak mulia khususnya memiliki kepedulian terhadap lingkungan (Obaid, 2013, p. 144).

Dari keempat point tersebut, point ketiga merupakan hal yang jarang diimplementasikan. Selama ini proses pembelajaran yang berlangsung belum sepenuhnya menjadi sarana untuk mengajarkan nilai-nilai agama berbasis lingkungan dalam setiap mata pelajaran, sehingga kurang mampu memberikan kontribusi pemahaman pada peserta didik. Oleh karena itu, diperlukan sebuah rekonstruksi pembelajaran berbasis nilai-nilai keagamaan berbasis lingkungan yang lebih holistik, futuristik, dan humanistik dengan melakukan transformasi nilai-nilai keagamaan dalam setiap pembelajaran sebagai upaya memupuk 
kesadaran dan rasa peduli terhadap lingkungan bagi peserta didik. Tugas guru tidak hanya transfer knowledge, akan tetapi harus mampu mentransfer nilainilai yang mampu menumbuhkembangkan sikap peduli lingkungan dan mampu melahirkan sikap hidup pada peserta didik secara afektif (Hasnidar, 2019, p. 114).

Perpaduan materi pembelajaran dengan nilai-nilai pendidikan agama berbasis lingkungan akan memberikan dampak bagi terbentuknya kesadaran lingkungan peserta didik. Internalisasi agama yang berhubungan dengan lingkungan salah satunya tersurat pada ayat "bencana dan berbagai kerusakan pada alam yang terjadi di muka bumi diakibatkan karena ulah manusia itu sendiri (QS. 30: 41)". Ayat tersebut bisa diajarkan dalam pembelajaran IPA, IPS, ataupun PPKn. Jika ayat tersebut terus menerus diselipkan dalam pembelajaran yang berhubungan dengan lingkungan, maka ia akan dipahami dengan baik dan menjadi fondasi untuk pembentukan kesadaran dalam melakukan perbuatan yang berhubungan dengan lingkungan(Karim, 2017, p. 323).

Terwujudnya suasana keagamaan di lembaga pendidikan Islam tidaklah mudah direalisasikan. Suasana keagamaan tidak hanya mengandalkan dukungan finansial, akan tetapi dibutuhkan partisipasi aktif dari semua pihak yang terlibat dalam lembaga pendidikan Islam, seperti tenaga pendidikan, kependidikan, dan terutama sosok sesepuh dari lembaga tersebut. Suasana keagamaan di dalam lingkungan pendidikan dengan berbagai aktivitas dan ragam bentuknya merupakan hal yang penting bagi terciptanya proses internalisasi nilai-nilai keagamaan pada peserta didik. Proses internalisasi nilainilai agama Islam yang berbasis lingkungan harus menjadi pembiasaan dalam berperilaku, dan segala aktivitas agar menginternalisasi pada jiwa peserta didik dan menjadi budaya bagi mereka dalam kehidupan sehari-hari.

\section{Eco-Pesantren}

Eco-pesantren terdiri dari dua kata yaitu eco dan pesantren. Eco berasal dari ecologi yakni sebuah disiplin ilmu yang mempelajari tentang hubungan interaksi makhluk hidup dengan lingkungan alamnya. Pesantren adalah institusi pendidikan Islam yang merupakan ciri khas Indonesia dan memiliki elemen pesantren yang terdiri dari pondok, pengajian kitab, masjid, santri, dan sesepuh pondok pesantren yang terkenal dengan sebutan kiai. Dengan demikian, eco-pesantren adalah sebuah institusi pendidikan Islam yang memiliki label "ramah lingkungan" dan memberikan kontribusi terhadap perlindungan alam dan pelestarian lingkungan (Aulia, 2017, p. 231).

Pesantren tidak hanya berfungsi sebagai lembaga yang menggeluti bidang keagamaan tetapi harus mampu menjadi sebuah lembaga sosial yang ikut 
berpartisipasi dalam menanggapi permasalahan di lingkungan sekitar termasuk kesadaran lingkungan. Upaya pelestarian alam yang dilakukan pesantren akan sangat membantu dalam pengembangan pemahaman dan peningkatan kesadaran masyarakat yang berkaitan dengan lingkungan. Program ini dikembangkan dengan metode kerja sama antar pemangku kepentingan. Metode yang dilakukan tidak hanya sebatas sosialisasi tetapi juga membutuhkan keterlibatan dan partisipasi masyarakat pesantren bersama dengan lembaga terkait. Langkah-langkah dalam pelibatan masyarakat dimulai dengan langkah masalah penelitian lapangan terkait dengan ekonomi, sosial, dan budaya Pesantren serta lingkungan pengelolaan. Langkah selanjutnya adalah berbagi pengetahuan dengan mentransfer pengetahuan seperti bagaimana menerapkan konsep Pesantren yang hijau melalui pengelolaan bank sampah, kampanye bersih dan sehat, eksplorasi lahan untuk tanaman produktif dan medis, dan program kurikulum hijau. Program-program tersebut diatur bersama dengan para pemangku kepentingan dari Pesantren dan masyarakat sekitar. Program ini menjadi mendesak karena tidak hanya mengatur Pesantren hijau dengan mengubah tidak peduli terhadap sikap lingkungan masyarakat sekitar tetapi juga menjadi motivator kepedulian lingkungan kepada masyarakat. Artinya program Eco-Pesantren ingin mengubah fungsi pesantren yang tidak hanya sebagai dasar pendidikan, moral, dan agama, tetapi juga menjadi penggagas kepedulian lingkungan di sekitar pesantren dan komunitas yang lebih luas (Herdiansyah, 2018, p. 313).

Program eco-pesantren pertama kali digagas oleh KH. Abdullah Gymnastiar di Pondok Pesantren Darut Tauhid. Eco-pesantren Darut Tauhid merupakan salah satu model pesantren yang didesain dan direncanakan sesuai dengan prinsip-prinsip berkelanjutan (Fua, 2013, p. 114). Program Ecopesantren merupakan model pendidikan lingkungan di pondok pesantren yang menarik banyak perhatian dari kalangan ulama dan ilmuwan. Program Ecopesantren kemudian diluncurkan oleh Kementerian Lingkungan Hidup yang bekerjasama dengan Kementerian Agama pada tanggal 5-6 Maret 2008 di Asrama Haji Pondok Gede. Menurut Kementerian Lingkungan Hidup (Fua, 2013, p. 119), program Eco-pesantren memiliki tujuan (1) peningkatan kesadaran ajaran islam yang akan dijadikan pedoman penting dalam berperilaku ramah lingkungan; (2) menerapkan ajaran islam dalam kegiatan sehari-hari; (3) menosialisasikan materi lingkungan hidup dalam kegiatan pondok pesantren; (4) terwujudnya kawasan pondok pesantren yang ramah lingkungan; (5) pemberdayaan pondok pesantren dalam peningkatan kualitas lingkungan yang agamis atau Islami, berlandaskan Alquran dan Sunnah Nabi; (6) peningkatan aktivitas yang memiliki nilai tambah baik dalam bidang sosial, ekonomi, dan ekologi; dan (7) pondok pesantren menjadi pusat pembelajaran 
wawasan lingkungan baik bagi komunitas pesantren maupun bagi masyarakat sekitar.

Keuntungan program eco-pesantren yang dilakukan oleh pondok pesantren menurut Kementerian Lingkungan Hidup Republik Indonesia (Fua, 2013, p. 120) adalah (1) Peningkatan efesiensi dalam pelaksanaan kegiatan operasional pondok pesantren dan penggunaan sumber daya; (2) menghemat sumber dana pondok pesantren dengan cara mengurangi konsumsi sumber daya; (3) peningkatan kondisi kegiatan pembelajaran yang lebih kondusif dan nyaman bagi seluruh warga pondok pesantren; (4) menciptakan kebersamaan bagi warga pondok pesantren, dan meningkatkan kesadaran lingkungan serta kesejahteraan masyarakat sekitar; (5) terhindarnya resiko dampak lingkungan dengan peningkatan berbagai aktivitas yang memiliki nilai tambah bagi pondok pesantren; dan (6) sebagai media pembelajaran bagi generasi muda tentang nilai-nilai kepedulian, pemeliharaan, dan pengelolaan lingkungan hidup yang baik dan benar.

Program eco-pesantren juga memiliki indikator yang meliputi pengembangan kebijakan pondok pesantren ramah lingkungan; pengembangan kurikulum lingkungan berbasis alam; (3) pengembangan kegiatan ekstrakurikuler berbasis tadabbur alam; (4) pengembangan dan atau pengelolaan sarana dan prasarana pendukung pondok pesantren.

Pendidikan eco-pesantren adalah salah satu bentuk pendidikan lingkungan di lingkungan pondok pesantren yang difokuskan terhadap penguatan moral generasi bangsa dalam rangka mengupayakan peningkatan kesadaran lingkungan yang didukung oleh tata nilai dan kehidupan spiritual Islam dengan cara meneruskan risalah Nabi Muhammad sesuai dengan Alquran dan Sunnah yang mengedepankan pengelolaan dan perlindungan lingkungan hidup untuk kemaslahatan manusia. Pengembangan nilai-nilai edukasi dalam konsep pendidikan berbasis eco-pesantren adalah sebuah nilai pendidikan dalam rangka mempersiapkan generasi selanjutnya sebagai kader ulama yang moderat dan memiliki peranan penting serta strategis dalam sebuah upaya pengelolaan dan perlindungan lingkungan hidup, harapan dengan adanya nilai edukasi tersebut adalah terbentuknya generasi muda yang memiliki moral, etika, dan agama, sehingga menghasilkan generasi muda berakhlak mulia dan berwawasan lingkungan serta mampu membawa kesejahteraan dan ketentraman secara berkesinambungan tanpa meminimalisir hak generasi selanjutnya (Fua, 2013, p. 124).

Program eco-pesantren sejalan dengan prinsip perlindungan ekologi Islam yang menjelaskan tentang ajaran Islam. Bahwasanya Islam telah mengajarkan penanaman sikap tanggung jawab atas peran manusia sebagai khalifah agar mampu memunculkan potensi pendidikannya melalui 
pembangunan konsep keberlangsungan atas kehidupan semua makhluk ciptaan Allah. Konsep tersebut memberikan kontribusi dalam penguatan pentingnya membangun sebuah alternatif imajinasi ekologi yang mendeskripsikan hubungan manusia dengan lingkungannya (Asmanto, 2015, p. 345).

\section{Program Adiwiyata di Lingkungan Madrasah}

Bentuk pengembangan kesadaran lingkungan di madrasah salah satunya dapat diimplementasikan melalui program Adiwiyata. Adiwiyata berasal dari dua kata "adi" dan "wiyata". Adi memiliki arti: agung, baik, besar, dan sempurna. Sedangkan "Wiyata" memiliki arti etika dan norma dalam kehidupan sosial, tempat seseorang mendapatkan ilmu pengetahuan. Dengan demikian Adiwiyata dapat diartikan sebagai sebagai tempat yang baik untuk memperoleh ilmu pengetahuan dan berbagai etika serta norma sebagai dasar bagi manusia untuk terciptanya kesejahteraan hidup dan meraih cita-cita pembangunan yang berkelanjutan (Haflah, 2018, p. 87).

Program ini merupakan bentuk penghargaan pemerintah kepada madrasah atas terselenggaranya program pendidikan berwawasan lingkungan. Tujuan dari program Adiwiyata adalah untuk mewujudkan warga madrasah yang memiliki karakter tanggung jawab dalam mengupayakan perlindungan dan pengelolaan lingkungan melalui tata kelola madrasah yang efektif dalam rangka mendukung program pembangunan yang berkelanjutan. Program Adiwiyata memiliki prinsip partisipatif dan berkelanjutan (Kadorodasih, 2017, p. 44).

Keuntungan dari pelaksanaan program Adiwiyata menurut Tim Adiwiyata Nasional (Haflah, 2018, p. 88) adalah (1) tercapainya standar kompetensi/ kompetensi dasar dan standar kompetensi lulusan (SKL) pendidikan dasar dan menengah; (2) efesiensi dalam penggunaan dana operasional madrasah semakin meningkat melalui pengurangan konsumsi dan penghematan berbagai sumber daya dan energi; (3) terciptanya kebersamaan warga madrasah dan lingkungan belajar mengajar yang kondusif dan nyaman; (4) menjadi wahana pembelajaran nilai-nilai pemeliharaan dan pengelolaan lingkungan secara langsung bagi warga madrasah dan masyarakat sekitar; (5) perlindungan dan pengelolaan lingkungan hidup semakin meningkat melalui kegiatan pengendalian kerusakan, pengendalian pencemaran, dan pelestarian fungsi lingkungan di madrasah.

Untuk mewujudkan tujuan program Adiwiyata, madrasah harus berusaha memenuhi empat indikator, yakni 1) pengembangan kebijakan sekolah peduli dan berbudaya lingkungan; 2) pengembangan kurikulum berbasis lingkungan; 3) pengembangan kegiatan berbasis partisipatif; dan 4) pengelolaan sarana pendukung ramah lingkungan (Haflah, 2018). 
Untuk mewujudkan pengembangan kesadaran lingkungan dalam pendidikan Islam, diperlukan sebuah pengelolaan yang mendukung terlaksananya pendidikan lingkungan oleh semua warga sekolah berdasarkan prinsip-prinsip dasar program adiwiyata yaitu partisipatif dan berkelanjutan. Kebijakan madrasah berwawasan lingkungan ditujukan untuk menciptakan warga madrasah khususnya peserta didik yang memiliki sikap peduli dan berbudaya lingkungan, yaitu peserta didik yang memiliki pengetahuan dan mampu berperilaku ramah lingkungan. Keberadaan madrasah peduli dan berbudaya lingkungan mampu membantu dalam pengurangan kerusakan lingkungan yang terjadi pada saat ini dan saat yang akan datang (Desfandi, 2017, p. 35).

Indikator dari pengembangan kebijakan sekolah peduli dan berbudaya lingkungan (Maulidiyah, 78) meliputi (1) pengembangan visi misi yang dituangkan dalam dokumen satu KTSP. Isi dari visi misi tersebut mencerminkan adanya upaya perlindungan dan pengelolaan lingkungan hidup yang kemudian dijabarkan dalam rencana program kerja dan kegiatan madrasah yang harus diketahui dan dipahami oleh semua warga madrasah; (2) adanya kebijakan tentang pengembangan materi pembelajaran pendidikan lingkungan hidup yang dituangkan dalam dokumen satu, dua, dan tiga KTSP; (3) adanya program atau kebijakan dalam peningkatan Sumber Daya Manusia (SDM) di bidang lingkungan melalui kegiatan terencana seperti seminar, lokakarya (workshop), berjumlah sedikitnya 50\% dari jumlah total tenaga pendidik dan non kependidikan, baik atas inisiatif sekolah maupun pihak lain selama empat tahun; (4) adanya kebijakan sekolah dalam upaya efesiensi penggunaan listrik, air, plastik, dan alat tulis kantor, termasuk petunjuk teknis dan pelaksanaannya yang didukung oleh komite dan melibatkan seluruh warga sekolah, serta adanya kegiatan monitoring secara rutin; (5) adanya kebijakan, peraturan (tata tertib) sekolah yang mengatur kesehatan dan kebersihan lingkungan sekolah, seperti pengelolaan sampah, ruang kelas, toilet, kantin, dan lingkungan sekolah yang berwawasan lingkungan melalui ketersediaan ruang terbuka hijau, upacara, seminar, serta penyebaran pamflet, spanduk dan booklet kepada semua warga sekolah; (6) adanya kebijakan sekolah dalam mengalokasikan dana sekolah secara rutin dalam RABS untuk kegiatan pengelolaan dan pembelajaran pendidikan lingkungan hidup melalui peningkatan kualitas sarana dan prasarana lingkungan sekolah dan peningkatan kualitas sumber daya manusia, pengembangan materi ajar minimal $10 \%$ dari total anggaran sekolah.

Berdasarkan hasil penelitian Kadorodasih ada beberapa faktor yang memengaruhi keberhasilan sebuah kebijakan, antar lain (1) sumber daya yang menjadi dukungan terealisasinya implementasi kebijakan, seperti sumber daya 
manusia, financial, informasi, sarana prasarana, dan kewenangan; (2) isi kebijakan hendaknya dirumuskan secara jelas sesuai dengan tujuan, manfaat, dan sasaran serta memperhatikan kemudahan dalam pelaksanaannya (3) kemampuan organisasi pelaksana dalam menetapkan hierarki kewenangan, jaringan sistem, gaya kepemimpinan, struktur birokrasi, evaluasi yang dipilih, peran setiap anggota organisasi, dan komunikasi; dan (4) kondisi lingkungan yang mendukung terwujudnya kebijakan seperti kepentingan, kekuasaan, kepatuhan, dan karakteristik sebuah lembaga (Kadorodasih, 2017, p. 46).

Pengembangan kesadaran lingkungan dalam pendidikan Islam bisa diimplementasikan melalui pengembangan kurikulum berbasis lingkungan. kurikulum berbasis lingkungan adalah kurikulum yang berisi tentang upaya perlindungan dan pengelolaan lingkungan hidup yang disampaikan melalui berbagai sumber belajar, metode, dan strategi yang dilakukan oleh guru di madrasah. Kurikulum berbasis lingkungan juga dapat diimplementasikan melalui penyampaian materi lingkungan dalam keberagaman kurikulum agar peserta didik dapat memahami lingkungan hidup yang dihubungkan dengan kehidupan sehari-hari (Fajarisma, 2014, p. 167).

Materi yang dimaksud bisa berupa mata pelajaran khusus maupun terintegrasi dalam mata pelajaran lain. Sebagaimana penjelasan dalam panduan Adiwiyata yang menjelaskan bahwa implementasi kebijakan berwawasan lingkungan bisa diaplikasikan dengan adanya mata pelajaran wajib dan/atau muatan lokal terkait dengan PLH yang dilengkapi dengan KBM (Ketuntasan Belajar Minimal) (Muslicha, 2015, p. 117).

Pendidikan lingkungan hidup salah satu usaha pelestarian lingkungan melalui pengajaran di sekolah secara formal. Akan tetapi, pendidikan lingkungan hidup bukan bidang studi yang berdiri sendiri, melainkan diintegrasikan ke dalam bidang studi di sekolah (Sya'ban, 2018, p. 88).

Pengembangan kurikulum berbasis lingkungan ditandai dengan 1) adanya pengembangan metode belajar berbasis lingkungan dan budaya yang dibuktikan dengan adanya aksi provokatif yang mendorong terciptanya karakter peduli dan berbudaya lingkungan, dilakukannya pendidikan lingkungan hidup secara proporsional antara teori dan praktik; 2) adanya pengembangan kegiatan kurikuler dan kokurikuler dalam peningkatan pengetahuan dan kesadaran siswa tentang lingkungan hidup yang dibuktikan dengan terealisasinya kegiatan perlindungan dan pengelolaan pendidikan lingkungan hidup yang terkait dengan pelaksanaan kurikulum; 3) tersedianya bahan ajar/literatur/referensi sedikitnya 10 judul buku yang relevan dengan isu lingkungan disertai dengan adanya dokumentasi hasil pembelajaran siswa dalam pendidikan lingkungan hidup (Sudarwati, 2012, p. 84). 
Kegiatan berbasis partisipatif adalah kegiatan pengelolaan lingkungan yang melibatkan seluruh warga madrasah dan masyarakat sekitar baik kegiatan yang diselenggarakan oleh madrasah itu sendiri maupun kegiatan yang dilakukan oleh institusi di luar madrasah. Kegiatan partisipatif dilakukan dengan memperhatikan dua standar yaitu pelaksanaan kegiatan perlindungan lingkungan dan kegiatan pengelolaan lingkungan yang terencana oleh warga madrasah serta menjalin kemitraan dengan institusi lain yang peduli dalam dunia lingkungan (Setyobudi, 2018, p. 15).

Pengembangan kegiatan berbasis partisipatif dilakukan melalui kegiatan: (1) diprogramkannya berbagai kegiatan ekstra kurikuler dalam pembelajaran persoalan lingkungan hidup bagi warga sekolah minimal satu kegiatan secara rutin yang bertema lingkungan hidup pada setiap program ekstra kurikuler dan terlaksananya kegiatan lingkungan yang berbasis partisipasif atas ide sekolah dengan melibatkan masyarakat sekitar lebih dari empat kegiatan per tahun; (2) berpartisipasi dalam kegiatan berbagai aksi lingkungan hidup yang dilakukan oleh pihak luar dan mengikuti lebih dari empat kegiatan sebagai kegiatan ekstrakurikuler siswa; (3) membangun kegiatan kemitraan atau memprakarsai pengembangan pendidikan lingkungan hidup dengan melakukan lebih dari lima kegiatan kemitraan dan memprakarsai berbagai kegiatan aksi lingkungan hidup dan senantiasa membangun kerjasama jangka panjang dan berkelanjutan untuk pengembangan program lingkungan hidup dengan berbagai pihak (Sudarwati, 2012, p. 85).

Sarana ramah lingkungan merupakan segala fasilitas yang digunakan dalam proses pembelajaran yang berasal dari bahan ramah lingkungan dan tidak menyebabkan timbulnya pencemaran dan atau kerusakan lingkungan (Kadorodasih, 2017, p. 49). Pengelolaan sarana pendukung madrasah yang ramah lingkungan (Ramdhani, 2018, p. 8) dapat dilakukan melalui beberapa indikator: (1) tersedianya sarana dan prasarana yang dapat mengatasi masalah lingkungan di madrasah sesuai dengan standar sarana dan prasarana seperti pembuatan biopori, pemilahan sampah pada tempat sampah, pembuatan bank sampah, penghijauan madrasah, pengelolaan dan pemanfaatan sampah organik, mendaur ulang sampah anorganik; (2) tersedianya sarana prasarana yang mendukung pembelajaran lingkungan di madrasah seperti penyediaan tempat pengomposan, apotek hidup, pemeliharaan tanaman obat keluarga (toga), taman madrasah, green house; (3) terpeliharanya sarana dan prasarana madrasah yang ramah lingkungan seperti ventilasi udara yang memadai dan alami, pemeliharaan pohon peneduh, pengaturan cahaya yang baik, dan pemeliharaan kantin yang sehat; (4) peningkatan dalam mengelola dan memelihara fasilitas sanitasi madrasah melalui pembuatan tata tertib dan daftar piket, pemeliharaan kebersihan toilet, pengadaan alat kebersihan, dan 
pengadaan air bersih; dan (5) membuat himbauan pemanfaatan air, listrik, dan alat tulis kantor dengan efisien melalui slogan hemat air, hemat listrik, dan lain-lain.

\section{Kesimpulan}

Bentuk pengembangan kesadaran lingkungan dalam pendidikan Islam bisa diimplementasikan dengan cara menginternalisasi nilai-nilai keagamaan berbasis lingkungan di lembaga pendidikan Islam, program eco-pesantren, dan program madrasah adiwiyata. Internalisasi nilai-nilai keagamaan berbasis lingkungan di lembaga pendidikan Islam dapat dilakukan melalui pendekatan terwujudnya metode pembelajaran dengan menggunakan pendekatan nilainilai agamis dalam setiap pembelajaran khususnya nilai-nilai agama yang berbasis lingkungan dan terwujudnya teladan dari pendidik yang memiliki akhlak mulia khususnya memiliki kepedulian terhadap lingkungan.

\section{DAFTAR PUSTAKA}

Asmanto, A. (2015). Revitalisasi Spiritualitas Ekologi Perspektif Pendidikan Islam. Jurnal Tsaqofah, 11(2), 333-354. https://doi.org/http://dx.doi.org/10.21111/tsaqafah.v11i2.272

Aulia, N. R. (2017). Pengelolaan Lingkunga Berbasis Pesantren (Studi Kasus di Pondok Pesantren Nurul Hakim Lombok NTB). Indonesian Journal of Multi Disiplinary Islamic Studies, 1(2), 229-244. https://doi.org/https://doi.org/10.21009/hayula.001.2.05

Desfandi, M. (2017). Kebijakan Sekolah Berwawasan Lingkungan Sebagai Upaya Mengembangkan Literasi Ekologis Peserta Didik. Jurnal Sosio Didaktika, 4(2).

Fajarisma, A. (2014). Analisis Implementasi Kurikulum Berbasis Lingkungan Hidup pada Program Adiwiyata Mandiri di SDN Dinoyo Malang. Jurnal Kebijakan Dan Pengembangan Pendidikan, 2(2), 166-173.

Fua, L. J. (2013). Eco-Pesantren: Model Pendidikan Berbasis Pelestarian Lingkungan. Jurnal Al-Ta'dib, 6(1), 113-125.

Haflah. (2018). Menanamkan Nilai Karakter Peduli Lingkungan Melalui Pendidikan Lingkungan Hidup Tantangan bagi FITK. Prosiding Halaqoh Nasional \& Seminar Internasional Pendidikan Islam Fakultas Tarbiyah Dan Keguruan UIN Sunan Ampel Surabaya, 83-91.

Haryanti. (2017). Manajemen Kurikulum Berwawasan Lingkungan di Sekolah Dasar Alam Pacitan Kabupaten Pacitan Tahun Pelajaran 2016/2017. IAIN 
Surakarta.

Hasnidar, S. (2019). Pendidikan Estetika dan Karakter Peduli Lingkungan Sekolah. Jurnal Serambi Ilmu, 20(1), 97-119.

Herdiansyah. (2018). Eco-Pesantren as a Basic Forming of Enviromental Moral and Theology. Kalam, 12(2), 303-326. https://doi.org/http://dx.doi.org/10.24042/klm.v/2i2.2834

Jufri. (2018). Pendidikan Lingkungan di Sekolah Dasar Nengeri 1 Baruga Kota Kendari. Jurnal Al-Ta'dib, 11(2), 164-181.

Kadorodasih. (2017). Implementasi Pendidikan Lingkungan Hidup melalui

Program Adiwiyata di Sekolah dasar Negeri Giwangan Yogyakarta. Jurnal Kalam, 6(4), 43-53.

Karim, A. (2017). Mengembangkan Kesadaran Melestarikan Lingkungan Hidup Berbasis Humanisme Pendidikan Agama. Jurnal Penelitian Pendidikan Islam, 12(2), 309-330.

Muslicha, A. (2015). Metode Pengajaran Dalam Pendidikan Lingkungan Hidup Pada Siswa Sekolah Dasar (Studi Pada Sekolah Adiwiyata di DKI Jakarta). Jurnal Pendidikan, 16(2), 110-126.

Muslim. (2003). Ilmu Islam Terapan Menggagas Paradigma Amali dalam Agama Islam. Yogyakarta: Pustaka Pelajar.

Obaid, Y. M. (2013). Religiusitias Lembaga Pendidikan Yang Berwawasan Lingkungan. Jurnal Al-Ta'dib, 6(1), 137-149.

Purwidianto. (2017). Pendidikan Lingkungan Hidup dalam Perspektif Islam. Jurnal Uhamka, 8(2), 225-228.

Ramdhani. (2018). Implementasi Program Adiwiyata dalam Pengelolaan Lingkungan Sekolah di SMPN 3 Sukabumi. Jurnal Pendidikan, 5(1), 110.

Setyobudi, F. (2018). Pendidikan Lingkungan Hidup di SMP Negeri 3 Kebumen Jawa Tengah. Jurnal Jipsindo, 5(1), 1-20.

Sudarwati, M. T. (2012). Implementasi Kebijakan Pendidikan Lingkungan Hidup Sekolah Menengah Atas Negeri 11 Semarang Menuju Sekolah Adiwiyata. Universitas Dipenogoro.

Sutoyo. (2015). Revolusi Paradigma Perlindungan dan Pengelolaan Lingkungan Hidup di Indonesia. Jurnal Pendidikan Pancasila Dan Kewarganegaraan, 28(1), 56-66.

Sya'ban, M. (2018). Tinjauan Mata Pelajaran IPS MPp Pada Penerapan Pendidikan Lingkungan Hidup Untuk Peduli Akan Tanggung Jawab Lingkungan. Jurnal Geografi Edukasi Dan Lingkungan, 1(2), 86-98. 
